\title{
DEVELOPMENT OF SOCIAL SKILLS IN LEARNING SOCIAL STUDIES IN PRIMARY SCHOOL
}

\author{
Nurlaila, M.Pd \\ STKIP Subang \\ laela.nur@gmail.com
}

\begin{abstract}
Referring to the standard social studies curriculum content subjects, 2006, one of the competencies that would be developed is to give students with a useful social knowledge, social skills, and intellectual, in fostering social attention as well as human resources who care as good Indonesian citizen and responsible realize national goals. To be able to successfully learn social studies, students should be equipped not only knowledge, but also the need to be explored and developed dimension of the skills and attitude value. Therefore, the focus of discussion in this paper is the urgency to develop social skills that are integrated into social studies teaching in elementary school. Processes and learning outcomes with social skills and building value is needed to equip learners to anticipate the future challenges that certainly will be more severe and complex. Teachers as curriculum developers are demanded to be skillful to bring atmosphere and learning activities which has purpose on developing basic skills and the cultivation and development of personality, temperament and character.. Implementation of educational based on social skills and coaching will is believed have valuable graduates outcome that have personality, temperament and good character. Therefore, the main task of basic education is to build students' character and have purpose build students from an early age in order to not fail be a perfect human.
\end{abstract}

Keywords: social skills, meaningful learning, character

\section{PENDAHULUAN}

Setiap mata pelajaran, termasuk IPS (IImu Pengentahuan Sosial) pada prinsipnya memiliki bahan ajar (instructional materials) berdimensi pengetahuan, keterampilan dan sikap/ nilai. Dalam struktur kurikulum 2006 mata pelajaran IPS di Sekolah Dasar (SD/MI), keseluruhan dimensi tersebut telah dikemas menjadi standar isi yang selanjutnya dijadikan pedoman oleh guru dalam mencapai standar kompetensi yang harus dikuasai siswa. Namun kenyataannya, pembelajaran IPS di SD belum secara optimal menyentuh keseluruhan dimensi tersebut. Proses dan hasil pembelajaran lebih menekankan dan memfokuskan pada pencapaian aspek intelektual atau ranah kognitif semata, sementara pengembangan aspek keterampilan dan pembinaan nilai/sikap masih diabaikan.
Belajar mengenai "bagaimana melakukan sesuatu" ialah hakikat dari belajar keterampilan. Skeel (1995) mendefinisikan bahwa keterampilan sebagai kemampuan menggunakan satu pemahaman untuk menyelesaikan tugas secara efektif dan tuntas. National Council of Social Studies (NCSS:1994; Skeel:1995) telah memetakan tujuh keterampilan dasar dalam pembelajaran IPS, antara lain mencakup keterampilan berpikir, keterampilan komunikasi dan keterampilan menghitung, keterampilan peta, globe, grafik, keterampilan waktu, keterampilan berpartisipasi sosial, keterampilan inkuiri, dan keterampilan komputer. Hal yang sama dikemukakan Bank (1990), bahwa sejumlah keterampilan-keterampilan yang dapat dikembangkan dalam pembelajaran IPS, meliputi: (1) keterampilan berpikir; (2) keterampilan akademik; (3) keterampilan ilmiah; dan (4) keterampilan sosial. 


\section{Didaktik : J urnal Pendidikan Guru Sekolah Dasar, ISSN : 2477-5673 \\ Sekolah Tinggi Keguruan dan IImu Pendidikan Subang Volume I Nomor 1, Desember 2015}

Dalam standar isi mata pelajaran IPS kurikulum 2006, tujuan pembelajaran IPS diarahkan untuk mengembangkan kemampuan berpikir kritis dan kreatif, inkuiri, memecahkan masalah, dan keterampilan sosial; (2) membangun komitmen dan kesadaran terhadap nilai-nilai sosial dan kemanusiaan; (3) meningkatkan kemampuan bekerjasama dan berkompetensi dalam masyarakat yang majemuk baik secara nasional maupun global. Selanjutnya bahan kompetensi yang harus dicapai siswa dalam pembelajaran IPS, salah satunya diarahkan untuk membekali anak didik dengan pengetahuan sosial yang berguna, keterampilan sosial, dan intelektual, dalam membina perhatian serta kepeduliaan sosialnya sebagai SDM Indonesia yang bertanggungjawab merealisasikan tujuan nasional. Pencapaian kompetensi tersebut dimaksudkan agar siswa dapat berhasil belajar IPS. Karena itu, mereka perlu dibekali dengan berbagai keterampilan termasuk keterampilan sosial.

Keterampilan sosial merupakan salah satu keterampilan dasar yang dibutuhkan oleh siswa untuk menerapkan secara aplikatif pemahaman mereka terhadap konsepkonsep dasar IPS. Misalnya, penjelasan konsep interaksi, interelasi dan interdependensi yang bersumber dari kajian sosiologi dapat diwujudkan dalam bentuk kegiatan kerjasama, saling menghargai terhadap perbedaan, menumbuhkan kesetiakawanan dan toleransi dan lain sebagainya. Alasan mengapa keterampilan sosial perlu dikembangkan dalam pembelajaran IPS SD, dikarenakan banyaknya permasalahan sosial yang sering ditemui siswa dalam kehidupan sehari-hari seperti peristiwa tawuran antarwarga, berbagai pelanggaran tata tertib, pengrusakan lingkungan serta fasilitas umum.

Selain itu, pengembangan keterampilan sosial telah dirumusan melalui Standar Kompetensi Lulusan No.23 Tahun 2006. Uraian kompetensi yang diharapkan dicapai siswa antara lain meliputi (1) mampu mencari, memilah dan mengolah informasi dari berbagai sumber; (2) mampu mempelajari hal-hal baru untuk memecahkan masalah sehari-hari; (3) memiliki keterampilan berkomunikasi baik lisan maupun tulisan. (4) memahami, menghargai dan mampu bekerjasama dengan orang lain yang majemuk;

mampu mentransformasikan kemampuan akademik dan beradaptasi dengan perkembangan masyarakat, lingkungan dan perkembangan global.

$$
\text { Mengacu pada landasan }
$$
pengembangan di atas, sudah seharusnya proses pembelajaran IPS diarahkan dan dikembangkan untuk mencapai tujuan-tujuan tersebut. Arah dan tujuan tersebut pada hakikatnya sejalan orientasi penyelenggaran pendidikan dasar (SD/MI). Pendidikan dasar sebagai salah satu jenjang pendidikan dalam sistem pendidikan nasional diibaratkan sebagai tiket masuk atau "paspor" untuk melanjutkan perjalanan berikutnya. Gagalnya proses pendidikan pada tahap ini diyakini akan berdampak serius terhadap penyelenggaraan pendidikan berikutnya. Bila mengacu pada ketentuan dalam Bab II Pasal 3 Undang-undang Sistem Pendidikan Nasional No.20 Tahun 2003, Orientasi penyelenggaraan pendidikan dasar sangat menekankan pada pembinaan kepribadian, watak dan karakter anak. Karena itu, untuk menggali dan mengembangkannya, perlu diintegrasikan melalui penyelenggaran proses pendidikan yang sarat dengan pengetahuan, keterampilan dan acuan nilai yang dapat berguna bagi kehidupan sehari-hari siswa dalam mengantisipasi tantangan ke depan yang dipastikan akan semakin berat dan kompleks. Guru sebagai pengembang kurikulum selanjutnya dituntut untuk mampu secara terampil menghadirkan 


\section{Didaktik : J urnal Pendidikan Guru Sekolah Dasar, ISSN : 2477-5673 \\ Sekolah Tinggi Keguruan dan IImu Pendidikan Subang Volume I Nomor 1, Desember 2015}

suasana dan aktivitas pembelajaran yang berorietansi pada pengembangan pengetahuan, keterampilan dan nilai ke dalam pembelajaran yang bernuansa aktif, inovatif, kreatif, efektif dan menyenangkan (PAIKEM).

\section{PEMBAHASAN}

Kebutuhan akan pengembangan keterampilan sosial dan pembinan sikap/nilai mulai nampak dan dirasakan penting setelah maraknya berbagai bentuk penyimpangan asusila, amoral di tengah masyarakat. Hampir setiap hari ada saja pemberitaan di media cetak dan elektronik tentang tawuran antar warga, konflik antar etnik dan agama, pembunuhan, pengrusakan lingkungan, pelanggaran tata tertib, peredaran dan pemakaian narkoba, bahkan pernah dilansir kasus pemerasan yang dilakukan geng anak usia sekolah dasar (SD). Tentu hal ini membuat gelisah dan cemas terutama akan dirasakan oleh para orangtua termasuk pihak lembaga sekolah yang mengemban tugas melakukan untuk mendidik, melatih dan membimbing anak didiknya. Ini persoalan serius dan perlu mendapat perhatian ekstra khususnya bagi pelakupelaku dunia pendidikan.

Pembahasan ini hendak mendiskusikan strategi pembelajaran yang mampu mengembangkan keterampilan sosial dan pembinaan aspek sikap/nilai siswa yang sekaligus merupakan kebutuhan dalam komponen pembelajaran di sekolah. Setiap hari, siswa dan guru menggunakan seperangkat keterampilan dan nilai untuk membuat keputusan. Misalnya pernyataan tentang apa yang baik dan apa yang buruk, apa yang layak dan tidak layak, apa yang boleh dan tidak boleh dilakukan. Untuk menjadi terampil, siswa memerlukan keterampilan untuk terlibat aktif dan berpartisipasi secara bertanggung jawab dalam mengidentifikasi dan memecahkan permasalahan-permasalahan sosial.
Dalam pembelajaran IPS, dimensi nilai yang terkandung ialah mengajarkan anak didik untuk mengembangkan sikap toleran, empati, bertanggungjawab dalam menggunakan hak dan kewajiban. Sumaatmadja (2005) mengemukakan bahwa nilai-nilai yang dapat dikembangkan dalam IPS meliputi: nilai edukatif, nilai praktis, nilai teoritis, nilai filsafat dan nilai ketuhanan. Lebih rinci, dijelaskan sebagai berikut.

a. Nilai edukatif, melalui pendidikan IPS, perasaan, kesadaran, penghayatan, sikap, kepeduliaan, bekerjasama, gotong royong dan tanggung jawab sosial peserta didik ditingkatkan.;

b. Nilai praktis, dalam pelaksanaanya nilai ini disesuaikan dengan tingkat umur dan kegiatan peserta didik sehari-hari seperti kebiasaan positif dalam dalam mengikuti perkembangan berita dan menghadapi permasalahan kehidupan sehari-hari;

c. Nilai teoritis, peserta didik dibina dan dikembangkan kemampuan nalarnya kearah dorongan mengetahui kenyata an (sense of reality), dan dorongan menggali sendiri dil apangan (sense or discovery). Kemamuan menyelidiki, meneliti dengan mengajukan berbagai pernyataan (sense of inquiry).

d. Nilai filsafat, peserta didik dikembang kan kesadaran dan penghayatan terhadap keberadaanya di tengahtengah masyarakat, bahkan ditengahtengah alam raya ini.

e. Nilai ketuhanan, menjadi landasan kita mendekatkan diri dan meningkatkan IMTAK kepada-Nya.

Guna mengakomodir pengembangan nilai-nilai tersebut, perlu upaya guru untuk secara kreatif menuangkannya ke dalam suasana dan aktivitas pembelajaran. Salah satu pendekatan pembelajaran yang dapat dijadikan alternatif ialah pendekatan keterampilan sosial.

Strategi Pembelajaran Keterampilan Sosial IPS di SD 


\section{Didaktik : J urnal Pendidikan Guru Sekolah Dasar, ISSN : 2477-5673 \\ Sekolah Tinggi Keguruan dan IImu Pendidikan Subang Volume I Nomor 1, Desember 2015}

Dalam upaya mengembangkan keterampilan sosial dalam pembelajaran IPS di SD, terdapat beberapa strategi pembelajaran yang relevan, diantaranya strategi konstruktivistik, aksi sosial (social action), dan strategi pengambilan keputusan (decision making).

Konsep pembelajaran konstruktivistik berangkat dari paradigma bahwa belajar bukanlah sekedar proses transfer pengetahuan, melainkan kegiatan mengkonstruksi seperangkat fakta dan konsep menjadi struktur pengetahuan yang diperoleh berdasarkan apa yang dilihat, didengar, dirasakan, serta dialami oleh siswa secara langsung. Selanjutnya kegiatan tersebut dibangun menjadi serangkaian proses yang dilakukan secara terus menerus. Dengan demikian, proses pembelajaran dapat lebih bermakna karena tidak hanya sekedar kegiatan mengumpulkan fakta melainkan mengembangkan usaha pemikiran yang kritis dan mendalam untuk membuat pemahaman baru. Selain itu, pembelajaran konstruktivistik mampu mendorong rasa ingin tahu (sense of curiosity) sebagai modal dasar untuk melatih dan mengembangkan kemampuan berpikir lebih lanjut

Melalui pembelajaran konstruktivistik, guru memiliki fungsi dan peran yang strategis dalam mendorong serta memfasilitasi siswa untuk terlibat aktif dalam proses pembelajaran. Upaya tersebut dapat dilakukan oleh guru melalui tahapan (1) guru dan siswa dapat memanfaatkan data mentah dan sumber utama dalam bentuk data primer maupun data sekunder untuk dikembangkan dan didiskusikan bersama-sama di kelas; (2) melalui penugasan yang terstruktur, guru dapat melatih dan mengembangkan kemampuan siswa untuk dalam mengklasifikasi, menganalisis, serta melakukan prediksi kemungkinan yang terjadi berdasarkan data dan informasi yang tersedia; (3) memberikan stimulus berupa kegiatan pembelajara yang menantang dan mendorong rasa ingin tahu siswa dalam memburu jawaban atas pertanyaan yang diajukan.

Selanjutnya pembelajaran konstrukti vistik dapat diterapkan ke dalam fasefase pembelajaran. Pertama, fase eksplorasi. Melalui fase ini siswa belajar memberikan respon terhadap situasi/ gejala. peristiwa/ fenomena yang disajikan. Selanjutnya siswa difasilitasi untuk menyelidiki gejala/fenomena tersebut melalui bimbingan guru. Melalui tahapan identifikasi masalah serta pencarian data dan informasi yang dibutuhkan, siswa kemudian diberikan kesempatan untuk menyampaikan gagasan, Kedua, fase pengenalan konsep. Melalui tahapan ini, guru memperkenalkan dan mengkaitkan konsep-konsep yang relevan serta ada hubungannya dengan gejala/fenomena yang diselidiki. Lewat diskusi, konsepkonsep yang telah dibangun dihubungkan dengan konteks masalah yang diamati. Ketiga, fase aplikasi konsep. Tahapan ini menyediakan kesempatan siswa untuk menggunakan konsep dalam kehidupan sehari dan pemecahan masalah. Berdasarkan tahapan dan kegiatan tersebut, keterampilan sosial pada gilirannya dapat digali dan dikembangkan secara optimal dalam pembelajaran IPS di SD.

Aksi sosial. Pembelajaran ini dikenal sebagai salah satu dari lima tradisi dalam pembelajaran IPS, yaitu " social studies as rational decision making and social action". Woolever \& Scott (1988) menjelaskan bahwa pengambilan keputusan (decision making) sangat melekat dengan tujuan aksi sosial (social action). Menurutnya, hasil belajar berupa kemampuan bagaimana membuat keputusan, di mana siswa dapat menerapkan sepanjang hidupnya untuk berbuat reflektif dan bertanggungjawab terhadap kemanusiaan ketika mereka dihadapkan persoalan individu dan persoalan sosial. Pembelajaran ini berupaya menekankan pada usaha guru untuk memfasilitasi dengan memberikan kesempatan kepada siswa untuk 


\section{Didaktik : J urnal Pendidikan Guru Sekolah Dasar, ISSN : 2477-5673 \\ Sekolah Tinggi Keguruan dan IImu Pendidikan Subang Volume I Nomor 1, Desember 2015}

melakukan perbuatan-perbuatan moral yang dilakukan baik secara perseorangan maupun secara berkelompok. Penjelasan Bank (1990) tentang pentingnya pembelajaran berbuat menyebutkan bahwa"....helping student to develop a greater sense of personal, social, and civic efficacy, and to develop greater skills in influencing their social and civic environment, should be the major goals of citizen action an participation project and activities". Menurut pendekatan ini ada dua tujuan utama pendidikan moral yang diharapkan dapat dimiliki oleh siswa. Pertama, siswa terlebih dahulu diberi kesempatan untuk melakukan perbuatan moral sesuai dengan yang mereka pilih berdasarkan pertimbangan alasan moral dan nilai-nilai mereka sendiri; Kedua, guru mengajak siswa untuk memahami konsep diri (self concept), yaitu dengan membantu siswa untuk melihat diri mereka sebagai makhluk individu dan makhluk sosial dalam interaksi seharihari ditengah kehidupan masyarakat.

Siswa sebagai sosok individu yang utuh, memiliki hak dan kewajiban yang harus dilaksanakan secara bertanggungjawab, artinya kebebasan yang mereka miliki senantiasa dibatasi oleh hak orang lain. Sejak awal siswa senantisa dibimbing dan dibekali kemampuan untuk peduli, peka terhadap persoalan sosial, memahami hak dan kewajiban, terampil menghargai perbedaan serta terlibat aktif dalam pemecahan permasalahan sosial. Pada gilirannya diharapkan aspek kepribadian, watak dan karakter siswa dapat terinternalisasi secara kuat sehingga dimasa yang akan datang mereka menjadi warga negara yang baik (well educated men and good citenship).

Woolever \& Scott (1988) mengembangkan sejumlah indikator yang menunjukan keterampilan partisipasi sosial yang meliputi dua aspek utama. Pertama, norma susila dalam kepedulian sosial. Indikator aspek ini meliputi antara lain (1) menggambarkan perasaan; (2) membangun empati; (3) membedakan dan mengidentifikasi ungkapan emosional; (4) menerima pandangan orang lain; (5) mengamati pengalaman perasaan orang lain; (6) bermain peran; (7) membangkitkan untuk mengungkapkan perasaan; (8) berperilaku sesuai dengan norma sosial; (9) memperlihatkan untuk menghargai hak-hak orang lain; (10) Saling mengingatkan sesama teman sebaya. Kedua, keterampilan partisipasi secara demokratis. Indikator aspek ini meliputi (1) mengidentifikasi situasi ke dalam keputusan bersama (aksi sosial); (2) membuat keputusan kolektif secara demokratis; (3) meminta dukungan; (4) menggerakan aksi sosial; (5) mengelola rencana peduli sosial; (6) tawar menawar atau negosiasi; (7) kompromi; (8) memilih; (9) melaksanakan keputusan bersama; (10) bekerja untuk mempengaruhi dan meyakinkan pada pemegang kekuasaan (DPR, Presiden, tokoh ormas, dll); (11) mengambil peran; (12) kerjasama; (13) berbagi; (14) bertindak sebagai pemimpin kelompok; (15) bertindak sebagai anggota kelompok; (16) berko ntribusi terhadap pekerjaan kelompok; (17) berbagi tugas secara adil; (18) mambuat aturan; (19) mengikuti aturan; (20) menerima sebuah konsekuensi secara sepenuh hati.

\section{PENUTUP}

Berdasarkan uraian di atas, disimpulkan bahwa siswa memerlukan banyak keterampilan untuk berhasil dalam belajar IPS. Keterampilan sosial adalah salah satu keterampilan dasar yang perlu diperkenalkan dan dikembangkan oleh guru dalam pembelajaran IPS di SD. Keuntungan yang dapat diperoleh diantaranya mendorong siswa untuk memiliki kepedulian terhadap persoalan sosial, kesadaran dan penghayatan sebagai makhluk sosial, rasa empati, toleran, bekerjasama, gotong royong.

Penguasaan terhadap keterampilan diharapkan pada gilirannya dapat 
bermanfaat dan digunakan secara aplikatif dalam kehidupan sehari-hari siswa. Tanpa penguasaan keterampilan dasar, siswa tidak akan dapat menemukan pengajaran IPS secara utuh dan menyeluruh serta akan mengalami kesulitan untuk melakukannya.

Karena itu, proses pembelajaran yang berangkat dan didasarkan pada keterampilan sosial serta pembinaan nilai yang tetap dikemas dalam nuansa pembelajaran aktif, inovatif, kreatif, efektif, dan menyenangkan diyakini akan melahirkan para lulusan yang berkepribadian, berkarakter, dan berwatak baik.

\section{DAFTAR PUSTAKA}

Skeel, J. Dorothy. (1995). Elementery Social Studies-Challenges for Tomorrow's World. Harcourt Brace College Publishers.

Woolever, M. Roberta and Scott, P. Kathryn. (1988). Active Learning in Social studies-Promoting Cognitive and Social Growth. Scott, Foresman and Company Boston London.

Undang-undang Nomor 20 Tahun 2003 tentang Sistem Pendidikan Nasional. Jakarta: Depdiknas

\begin{tabular}{lll} 
& Nomor 22 Tahun 2006 \\
\hline tentang Standar Isi. Jakarta: \\
Depdiknas
\end{tabular}

Nomor 23 Tahun 2006 tentang Standar Kompetensi Lulusan (SKL). Jakarta: Depdiknas

Bank, A. James. (1990). Teaching Strategies for The Social StudiesInquiry, Valuing, and Decision Making. Longman New York and London.

Sumaatmadja, Nursid.(2005). Konsep Dasar IPS. Jakarta: Pusat Penerbitan Universitas Terbuka. 